\title{
SR\&NI Atom Transfer Radical Random Copolymerization of Styrene and Methyl Methacrylate: Incorporation of Diatomite Platelets
}

\author{
Khezrollah Khezri, ${ }^{1}$ Hassan Alijani ${ }^{2}$ and Yousef Fazli ${ }^{3}$ \\ ${ }^{1}$ Young Researchers and Elite Club, Central Tehran Branch, Islamic Azad University, Tehran, Iran \\ ${ }^{2}$ Department of Chemistry, Faculty of Science, Shahid Chamran University, Ahvaz, Iran \\ ${ }^{3}$ Department of Chemistry, Faculty of Science, Arak Branch, Islamic Azad University, Arak, Iran, P.O. \\ Box 14155-6455, Tel: +988633412603 \\ *Corresponding author:E-mail: youseffazli75@gmail.com,y-fazli@iau-arak.ac.ir
}

Received: $10-03-2018$

\begin{abstract}
Mesoporous diatomite platelets were employed to prepare various random poly (styrene-co-methyl methacrylate)/diatomite composites by in situ simultaneous reverse and normal initiation technique for atom transfer radical random copolymerization (SR\&NI ATRP) technique. Nitrogen adsorption/desorption isotherm, SEM and TEM were employed for evaluating some inherent properties of the pristine diatomite platelets. Conversion and molecular weight determinations were carried out using GC and SEC respectively. Addition of $3 \mathrm{wt} \%$ diatomite platelets leads to increase of conversion from 76 to $92 \%$. Molecular weight of poly (styrene-co-methyl methacrylate) chains increases from 12893 to 14907 $\mathrm{g} \mathrm{mol}^{-1}$ by addition of $3 \mathrm{wt} \%$ mesoporous diatomite; however, polydispersity index values increases from 1.18 to 1.44 . Copolymers composition was evaluated using ${ }^{1} \mathrm{H}$ NMR spectroscopy. Increasing thermal stability of the nanocomposites is demonstrated by TGA. Differential scanning calorimetry shows an increase in glass transition temperature from 67.6 to $73.4^{\circ} \mathrm{C}$ by adding $3 \mathrm{wt} \%$ of mesoporous diatomite platelets.
\end{abstract}

Keywords: Nanocomposite; random poly (styrene-co-methyl methacrylate); mesoporous diatomaceous earth platelets; In situ SR\&NI ATRP

\section{Introduction}

During the last decades, polymer based nanocomposites have attracted much attention in the industrial and academia. ${ }^{1-2}$ Addition of low volume of nano-filler in the polymer matrix results in considerable improvements in several properties (such as thermal and mechanical properties). ${ }^{2-3}$ Nanocomposites as a novel class of materials present unique features that are not shared by traditional composites. Nanocomposites can simultaneously present useful properties of organic phase (e.g., flexibility, ductility, and processability) and nano-inorganic phase (e.g., rigidity and thermal stability). ${ }^{4-5}$ Nanocomposites can be categorized into three main types depending on the number of nanometer regimes of the dispersed filler(s); a) three dimensions are in the order of nanometers such as spherical silica nanoparticles. b) two dimensions are in the nanometer scale such as nanotubes or whiskers. c) one dimension in the nanometer range such as clay platelets. ${ }^{6-7}$ Melt intercalation, solution blending, and in situ polymerization are three famous pathways to prepare polymer nanocomposites that the latter consists of polymerization of monomer(s) in the presence of nano-fillers. $^{8-9}$

Diatomite or diatomaceous earth is the fossilised remains of single cell photosynthetic aquatic algae that can be found in large quantities in marine and fresh-water systems. Diatomite is mainly consists of amorphous silica $\left(\mathrm{SiO}_{2} \mathrm{nH}_{2} \mathrm{O}\right)$ that is originated from opalescent frustules of diatoms. Diatomite is classified as non-crystalline opal-A according to the mineralogical classification. ${ }^{10-12} \mathrm{Al}-$ though amorphous silica is the main component of the diatomite, it contains some impurities such as certain minerals and chemicals (especially alumina and ferric oxide). ${ }^{13-14}$ Diatomite is an insulator and non-inflammable, insoluble in water and contains up to $80-90 \%$ voids in its 
structure. Diatomite can be easily obtained at a low cost because diatomaceous silica is the most abundant form of silica on the earth. ${ }^{12,15-16}$ Diatomaceous earth possesses highly porous structure, low density, high surface area, suitable stability in chemical property, high permeability and small particle size in which makes it suitable for a wide range of industrial applications such as filter aid, adsorbent, insulating material, catalyst support or carrier, natural insecticide or grain protectant and etc. ${ }^{14,16-18}$

Controlled radical polymerization (CRP) techniques are investigated to introduce suitable pathways for the preparation of various polymers with predetermined molecular weight, narrow polydispersity index (PDI) values, desired composition and functionalities. Among three most common CRP methods, which are namely nitroxide-mediated polymerization $(\mathrm{NMP})^{19}$, reversible addition fragmentation chain transfer (RAFT), ${ }^{20}$ and atom transfer radical polymerization (ATRP), ${ }^{21}$ ATRP presents some unique benefits such as applicability to a wide variety of monomers and polymerization systems, great industrialization prospects, commercial availability of its reactants and also application of different initiation technique. ${ }^{21}$ These unique features lead to ATRP becomes as a popular producer for polymer chemists.

A review of literatures indicates that application of diatomite as filler to synthesize polymer/diatomite composites have attracted considerable attention. Karaman et al. have prepared polyethylene glycol (PEG)/diatomite composite as a novel form-stable composite phase change material (PCM) in which the PCM was prepared by incorporating PEG in the pores of diatomite. ${ }^{22} \mathrm{Li}$ et al. have synthesized conducting diatomite by polyaniline on the surface of diatomite. Linkage of polyaniline on the surface of diatomite is attributed to the hydrogen bond between the surface of diatomite and polyaniline macromolecules. ${ }^{23} \mathrm{Li}$ et al. have also prepared fibrillar polyaniline/diatomite composite by one-step in situ polymerization. According to their results, the polyaniline/diatomite composite can be applied as fillers for electromagnetic shielding materials and conductive coatings. ${ }^{24}$ In addition, other studies such as investigating the effects of extrusion conditions on dieswell behavior of polypropylene/diatomite composite melts and crystallization behaviors and foaming properties of diatomite-filled polypropylene composites have been performed. ${ }^{25-26}$

In this study, we take unique advantages of simultaneous reverse and normal initiation technique for atom transfer radical polymerization (SR\&NI ATRP) method to synthesize random poly (styrene-co-methyl methacrylate)/diatomite nanocomposites. Among different initiation techniques for ATRP, an interesting initiation technique namely SR\&NI was employed to prepare tailor-made polymer matrices. SR\&NI ATRP is selected for its abundant advantages such as application of transition metal complex in its high oxidation state and decrement of metal concentration in the final products. Moreover, we have tried to investigate the effect of diatomite platelets loading on the kinetics parameters (conversion, molecular weights, and PDI values) of the SR\&NI ATRP of styrene and methyl methacrylate. Evaluation of diatomite platelets as an appropriate replacement of natural clay platelets is also performed by examining thermal properties of the prepared nanocomposites.

\section{Experimental}

\section{1. Materials}

Diatomite earth sample was obtained from Kamel Abad-Azerbaijan, Iran. It was dispersed in $100 \mathrm{ml}$ distilled water by magnetic stirring and then it was kept constant until some solid impurities were dispersed. The particles were separated with filter paper and dried at $100^{\circ} \mathrm{C}$ for $8 \mathrm{~h}$. Styrene (St, Aldrich, 99\%) and methyl methacrylate (MMA, Merck, 99\%) were passed through an alumina-filled column, dried over calcium hydride, and distilled under reduced pressure $\left(60^{\circ} \mathrm{C}, 40 \mathrm{~mm} \mathrm{Hg}\right)$. Copper(II)

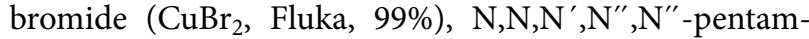
ethyldiethylenetriamine (PMDETA, Aldrich, 99\%), 2,2'azobisisobutyronitrile (AIBN, Acros), ethyl alpha-bromoisobutyrate (EBiB, Aldrich, 97\%), anisole (Aldrich, 99\%), tetrahydrofuran (THF, Merck, 99\%), and neutral aluminum oxide (Aldrich, 99\%) were used as received.

\section{2. Simultaneous Reverse and Normal Initiation Technique for Atom Transfer Radical Random Copolymerization of Styrene and Methyl Methacrylate}

SR\&NI ATRP of styrene and methyl methacrylate was performed in a $200 \mathrm{ml}$ three-neck lab reactor, which equipped with a reflux condenser, nitrogen inlet valve, and a magnetic stir bar that was placed in an oil bath. A typical batch of copolymerization was run at $110^{\circ} \mathrm{C}$ with the molar ratio of 150:0.12:0.2:0.2:1 for [M]:[AIBN]:[Cu$\mathrm{Br}_{2}$ ]:[PMDETA]:[EBiB] giving a theoretical copolymer molecular weight of $15320 \mathrm{~g} \mathrm{~mol}^{-1}$ at $100 \%$ conversion. At first, styrene $(8.34 \mathrm{ml}, 0.07 \mathrm{~mol})$, methyl methacrylate $(6.2 \mathrm{ml}, 0.05 \mathrm{~mol}), \mathrm{CuBr}_{2}(0.05 \mathrm{~g}, 0.23 \mathrm{mmol})$, PMDETA $(0.04 \mathrm{ml}, 0.23 \mathrm{mmol})$ and anisole $(10 \mathrm{ml})$ were added to the reactor. Then, it was degassed and back-filled with nitrogen three times, and then left under $\mathrm{N}_{2}$ with stirring at room temperature. The solution turned green color since the $\mathrm{CuBr}_{2}$ /PMDETA complex was formed. When the majority of the metal complex had formed, reaction temperature was increased to $110^{\circ} \mathrm{C}$ during $5 \mathrm{~min}$. Subsequently, predeoxygenated solution of AIBN $(0.02 \mathrm{~g}, 0.14$ $\mathrm{mmol})$ in styrene $(5 \mathrm{ml}, 0.04 \mathrm{~mol})$ and predeoxygenated $\mathrm{EBiB}(0.17 \mathrm{ml}, 1.1 \mathrm{mmol})$ were injected into the reactor to start the copolymerization reaction. Samples were taken at the end of the reaction to measure the final conversion. 


\section{3. Preparation of Random Poly (Styrene- Co-Methyl Methacrylate)/Diatomite Nanocomposites Via In Situ SR\&NI ATRP}

For preparation of nanocomposites, a desired amount of diatomite platelets was dispersed in $5 \mathrm{ml}$ of styrene and the mixture was stirred for $23 \mathrm{~h}$. Then, the remained $3.34 \mathrm{ml}$ of styrene was added to the mixture. Subsequently, copolymerization procedure was applied accordingly. Designation of the samples with the percentage of pristine diatomite platelets is presented in table 1 . In this designation, NPSM refers to neat random poly (styrene-co-methyl methacrylate) and RPSMN "X" implies different nanocomposites of random poly (styrene-co-methyl methacrylate) with various percentages of diatomite platelets loading.
NOWAX capillary column for the separation. Size exclusion chromatography (SEC) was used to measure the molecular weight and molecular weight distribution. A Waters 2000 ALLIANCE with a set of three columns of pore sizes of 10000,1000 , and $500 \AA$ was utilized to determine polymer average molecular weight and PDI values. Proton nuclear magnetic resonance spectroscopy $\left({ }^{1} \mathrm{H}\right.$ NMR) spectra were recorded on a Bruker $300-\mathrm{MHz}$ ${ }^{1} \mathrm{H} \mathrm{NMR}$ instrument with $\mathrm{CDCl}_{3}$ as the solvent and tetramethylsilane as the internal standard. Thermal gravimetric analysis (TGA) was carried out with a PL thermo-gravimetric analyzer (Polymer Laboratories, TGA 1000, UK). Thermal analysis were carried out using a differential scanning calorimetry (DSC) instrument (NETZSCH DSC 200 F3, Netzsch Co, Selb/Bavaria, Germany).

\begin{tabular}{lccc}
\hline Sample & $\begin{array}{c}\text { Method } \\
\text { of Preparation }\end{array}$ & $\begin{array}{c}\text { Proportion of } \\
\text { Pristine Diatomite } \\
\text { Platelets (wt\%) }\end{array}$ & $\begin{array}{c}\text { Dispersion } \\
\text { Time Prior to the } \\
\text { Copolymerization (h) }\end{array}$ \\
\hline NPSM & SR\&NI ATRP & 0 & - \\
RPSMN 1 & In situ SR\&NI ATRP & 1 & 23 \\
RPSMN 2 & In situ SR\&NI ATRP & 2 & 23 \\
RPSMN 3 & In situ SR\&NI ATRP & 3 & 23 \\
\hline
\end{tabular}

\section{4. Separation of Random Copolymer Chains from Diatomite Platelets and Catalyst Removal}

For separating of random poly (styrene-co-methyl methacrylate) chains from diatomite particles, nanocomposites were dissolved in THF. By high-speed ultracentrifugation $(10000 \mathrm{rpm})$ and then passing the solution through a 0.2 micrometer filter, poly (styrene-co-methyl methacrylate) chains were separated from diatomite particles. Subsequently, copolymer solutions passed through an alumina column to remove catalyst species.

\subsection{Characterization}

Materials porosity was characterized by $\mathrm{N}_{2}$ adsorption/desorption curves obtained with a Quntasurb QS18 (Quntachrom) apparatus. Surface morphology of the pristine diatomite particles was examined by scanning electron microscope (SEM, Philips XL30 and LEO$1455 \mathrm{VP}$ ) with acceleration voltage of $20 \mathrm{kV}$ and transmission electron microscope (TEM), Philips EM 208 (The Netherlands) with an accelerating voltage of 120 $\mathrm{kV}$. Gas chromatography (GC) is a simple and highly sensitive characterization method and does not require removal of the metal catalyst particles. GC was performed on an Agilent-6890N with a split/splitless injector and flame ionization detector, using a $60 \mathrm{~m} \mathrm{HP-IN-}$

\section{Results and Discussion}

FTIR analysis of the pristine diatomite platelets indicates that although the pristine diatomite platelets are rehydrated, during the preparation process and obtaining the spectrum some water molecules may be re-adsorbed $\left(3434 \mathrm{~cm}^{-1}\right)$. In this spectrum, the strong peak at 1098

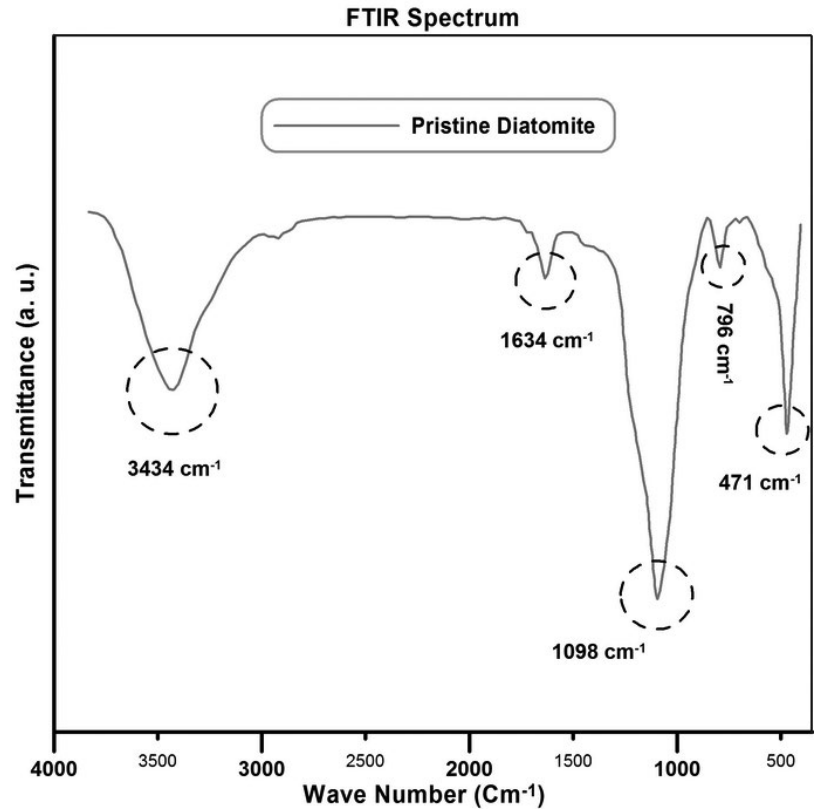

Figure 1: FTIR spectrum of the pristine diatomite sample 
$\mathrm{cm}^{-1}$ is attributed to the stretching mode of siloxane (Si$\mathrm{O}-\mathrm{Si}$ ). In addition, the peak at $471 \mathrm{~cm}^{-1}$ and $796 \mathrm{~cm}^{-1}$ are associated with the asymmetric stretching mode of siloxane bonds the vibration of $\mathrm{O}-\mathrm{H}$ respectively. ${ }^{27-29}$

Nitrogen adsorption/desorption isotherm is employed to precise study on the porous structure of the diatomite platelets. Nitrogen adsorption/desorption isotherm of the diatomite platelets is provided in figure 2. According to this figure, the shape of isotherm is similar to the IV type isotherms according to the IUPAC classification and confirms that diatomite platelets have mesoporous structure. ${ }^{30-31}$ The hysteresis is associated with the filling and emptying of the mesopores by capillary condensation. A sharp increase in the nitrogen adsorbed quantity near the relative pressure of 1 demonstrates the existence of macropores in the pure diatomite platelets and therefore non-uniform pore size distribution can be concluded. ${ }^{32}$

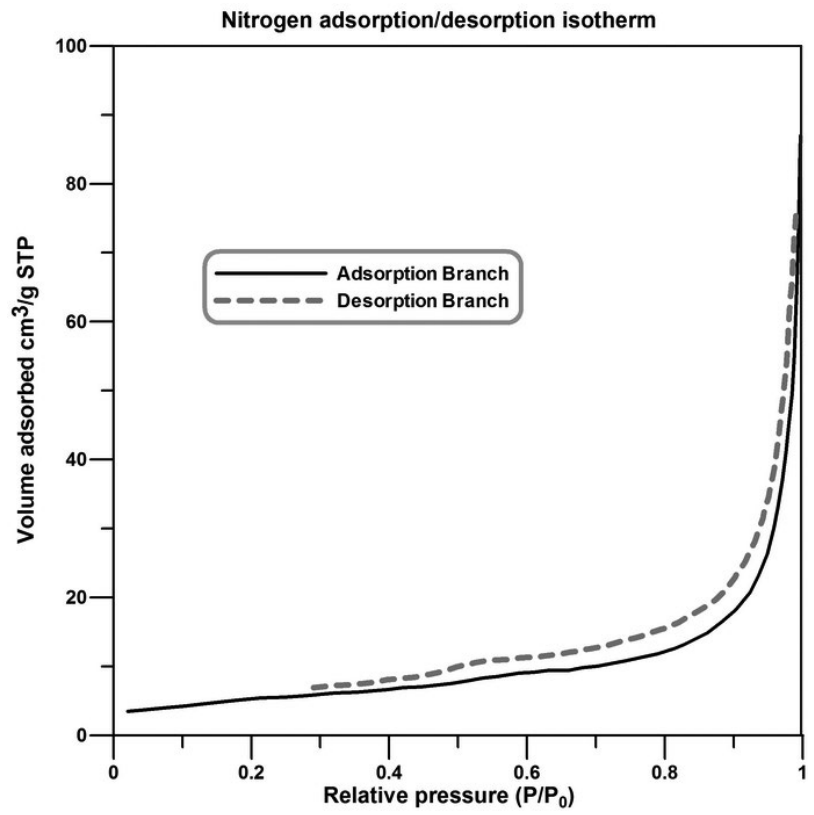

Figure 2: Nitrogen adsorption/desorption isotherm of the pristine diatomite sample

According to extracted data from the nitrogen adsorption/desorption isotherms, surface area of the pristine diatomite platelets is calculated $20.409 \mathrm{~m}^{2} / \mathrm{g}$. Also, average pore diameter is estimated around $28.13 \mathrm{~nm}$.

SEM image of the pristine diatomite platelets is shown in figure 3. According to this image, diatomite sample is composed of plaque plate particles with spherical pores. These plates have regular pores and sometimes are aggregated.

Figure 4 represents TEM image of the pristine diatomite platelets. According to this image, pristine diatomite sample belongs numerous regularly spaced rows of pores in its structure that this observation is confirmed with SEM images. In addition, average pore diameter is estimated around $45 \mathrm{~nm}$.

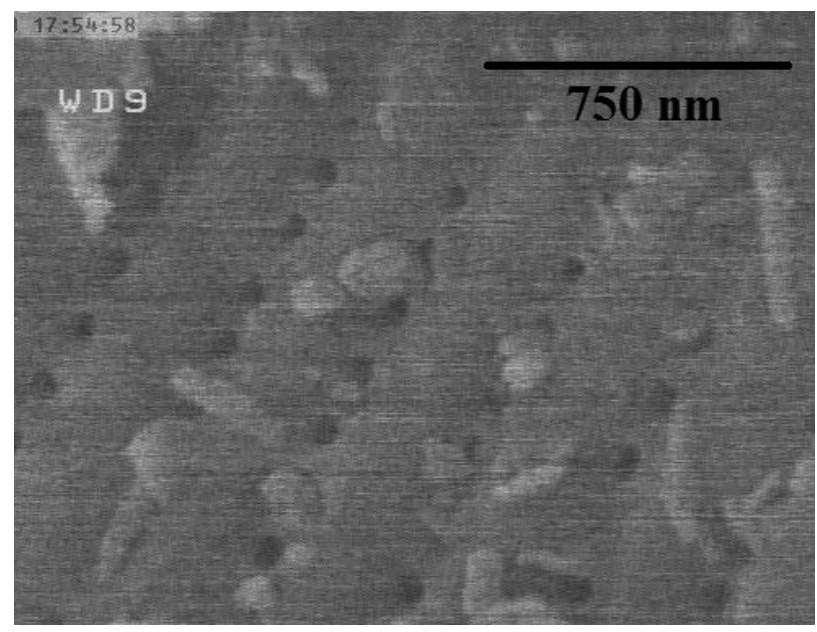

Figure 3: SEM image of the pristine diatomite sample

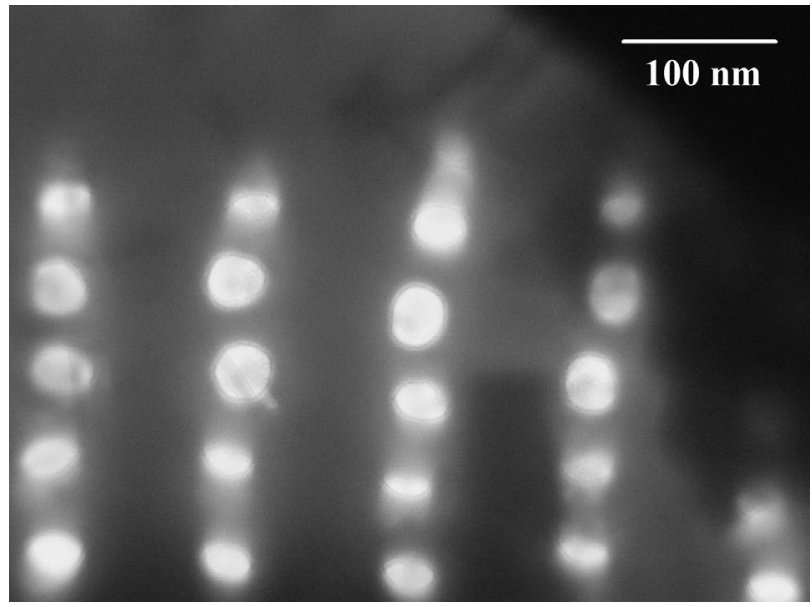

Figure 4: TEM image of the pristine diatomite sample

General mechanism for SR\&NI ATRP is illustrated in figure 5. SR\&NI ATRP employs transition metal complex in its high oxidation state and therefore by using this initiation technique oxidation problems can be circumvented.

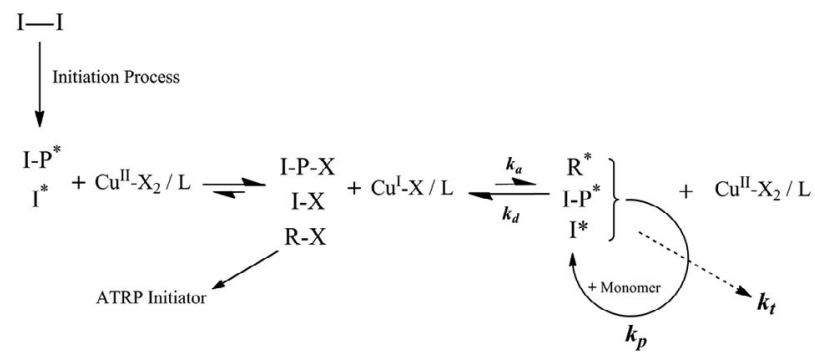

Figure 5: General mechanism for SR\&NI ATRP

General procedure for the synthesis of well-defined random poly (styrene-co-methyl methacrylate) chains via SR\&NI ATRP in the presence of the diatomite platelets is illustrated in figure 6 . 

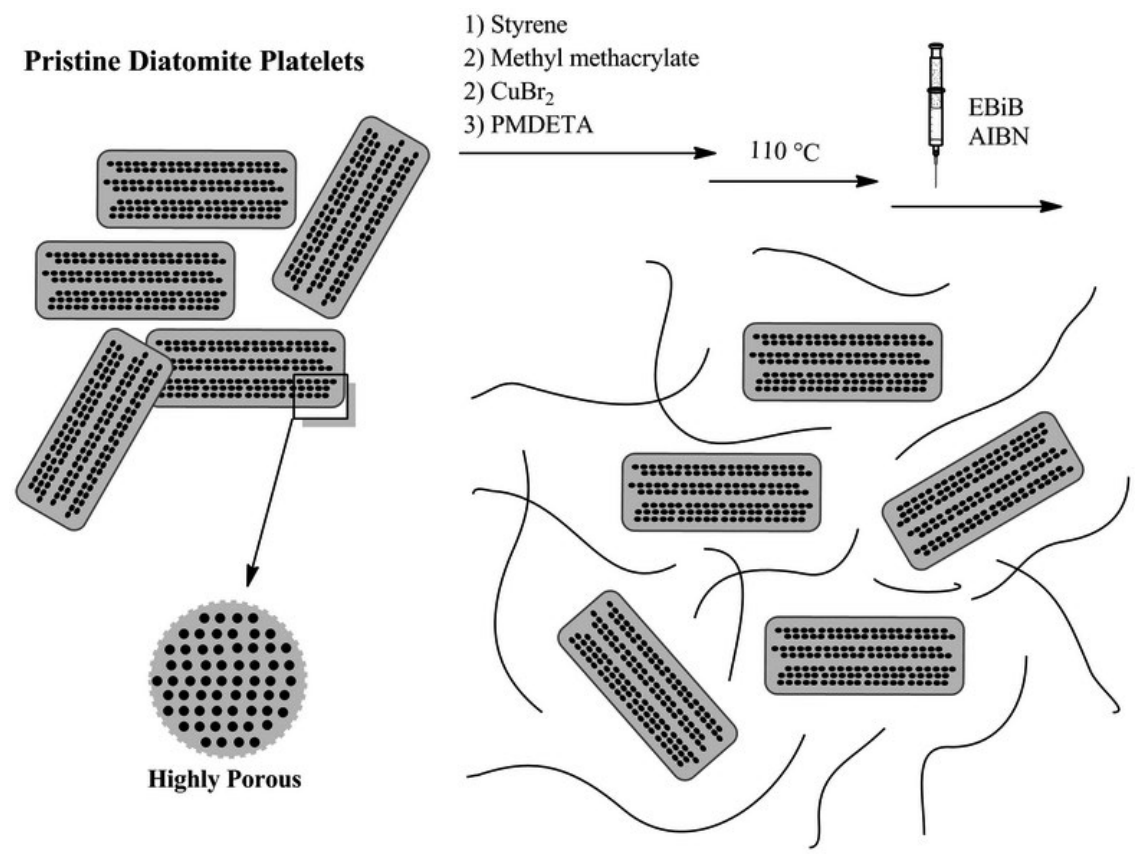

Poly (styrene-co-methyl methacrylate)/Mesoporous Diatomite Nanocomposite

Figure 6: General procedure for the synthesis of well-defined random poly (styrene-co-methyl methacrylate)/diatomite nanocomposites via in situ SR\&NI ATRP

Although reverse ATRP (RATRP) is a suitable pathway for circumventing oxidation problems (application of transition metal complex in its high oxidation state), SR\&NI ATRP presents additional useful properties and therefore can be considered a more appropriate pathway to over come oxidation problems. SR\&NI ATRP applies low-

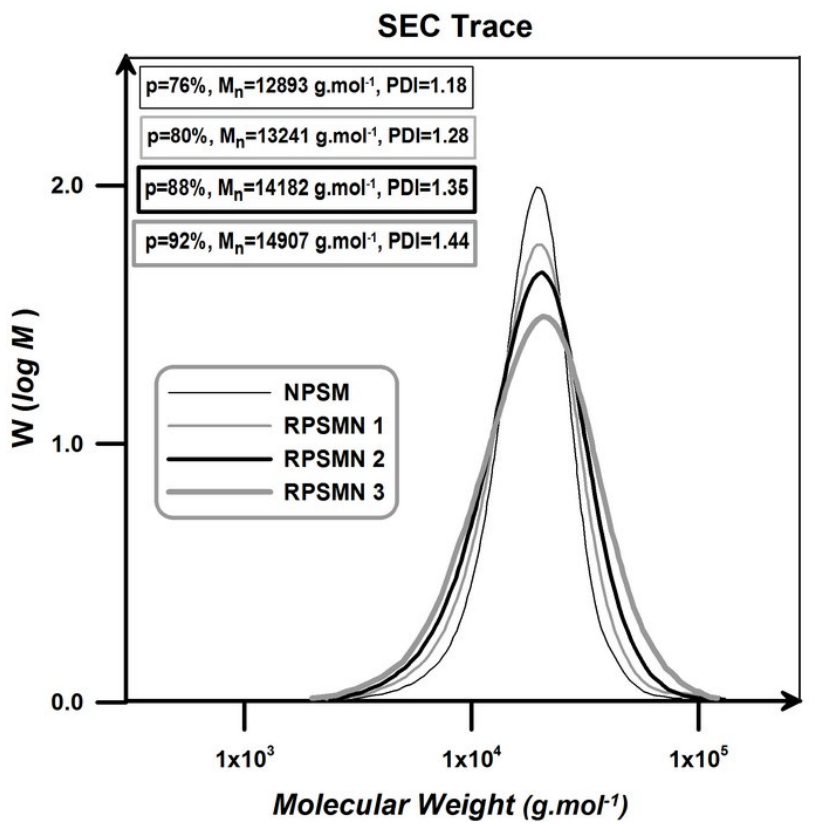

Figure 7: SEC traces of the neat random poly (styrene-co-methyl methacrylate) and its nanocomposites er metal concentration in its initial components and therefore lower concentration of transition metals will be existed in the final products. ${ }^{33}$

SEC traces of the neat random poly (styrene-co-methyl methacrylate) and its different nanocomposites are presented in figure 7. As it can be seen, SEC traces of the neat random poly (styrene-co-methyl methacrylate) and all of the nanocomposites display monomodal peaks corresponding to the molecular weight values predetermined by the molar ratio of monomer to initiator. Neat random poly (styrene-co-methyl methacrylate) reveals narrow distribution and relatively low PDI value in which this result can be employed to demonstrate successful establishment of SR\&NI ATRP.

SR\&NI ATRP of styrene and methyl methacrylate without diatomite platelets results in well-defined random copolymer chains with low PDI value. By adding diatomite platelets, conversion and molecular weight were increased. By addition of only $3 \mathrm{wt} \%$ of the diatomite platelets, conversion increases from 76 to $92 \%$. Increments of conversion and molecular weight of the products by adding diatomite platelets can be attributed to the pendant hydroxyl groups on the surface (and pores) of the diatomite platelets. In general, polar solvents (especially hydroxyl containing ones like water, phenol, and carboxylic acids) exert a rate acceleration effect on the copolymerization systems for increasing radical activation rate and also reducing radical recombination rate. Pendant hydroxyl groups on the surface (and pores) of the diatomite platelets can possibly cause a polarity change into the reaction medium. In 
addition, negatively charged surface (pendant hydroxyl groups on the surface of the diatomite platelets) could absorb and gather positively charged catalyst ( $\mathrm{Cu}$ ions) and consequently enhances the chain growth rate. Similar effects for adding other nano-fillers such as clay nano-sheets and MCM-41 nanoparticles on polymerization rate were also presented elsewhere. ${ }^{34-35}$ PDI values of the random poly (styrene-co-methyl methacrylate) chains increases by the addition of diatomite platelets loading. This is mainly attributed to the impurity role of the diatomite platelets. These platelets act as an impurity in the copolymerization medium and therefore cause the molecular weight distribution of the resultant copolymers to be increased; PDI value increases from 1.18 to 1.44 by loading of $3 \mathrm{wt} \%$ diatomite platelets. ${ }^{36}$ Extracted data from SEC traces of the neat random poly (styrene-co-methyl methacrylate) and its nanocomposites is summarized in table 2.

By comparing these results with the previous study some useful conclusions can be obtained; $a$ ) Application of reverse atom transfer radical polymerization (RATRP) results in higher conversion in the same loadings of diatomite platelets. $b$ ) It is very interesting that variation of the final conversion by addition of $3 \mathrm{wt} \%$ of diatomite is equal for both of the systems (16\% increment in conversion by adding $3 \mathrm{wt} \%$ of diatomite).c) Both of the systems present similar behavior in the case of the variation of the molecular weights. $d$ ) As it expected, application of SR\&NI ATRP results in lower PDI values in comparison with RATRP. $f$ ) According to the PDI values, SR\&NI ATRP system results in higher variation in PDI values by addition of diatomite platelets in comparison with the RATRP system. ${ }^{37}$

Theoretical molecular weight is calculated by using Equation 1:

$$
M_{n}^{\text {Theo }}=\frac{[M]_{0}}{[A I B N]_{0}} \times \text { Conv } \times M_{\text {monomers }}
$$

where, $[\mathrm{M}]_{0}$ and $[\mathrm{AIBN}]_{0}$ are initial concentration of the monomers and ATRP initiator, respectively. Conversion is denoted by Conv. and the symbol of the average molecular weight of the monomers is $\mathrm{M}_{\text {monomers }}$.

An appropriate agreement between the theoretical and experimental molecular weights in combination with acceptable PDI values (PDI $<1.5)$ can be considered as an appropriate evidences for controlled nature of the copolymerization. Also, color change of the reaction media dur-
${ }^{1} \mathrm{H}$ NMR Pattern

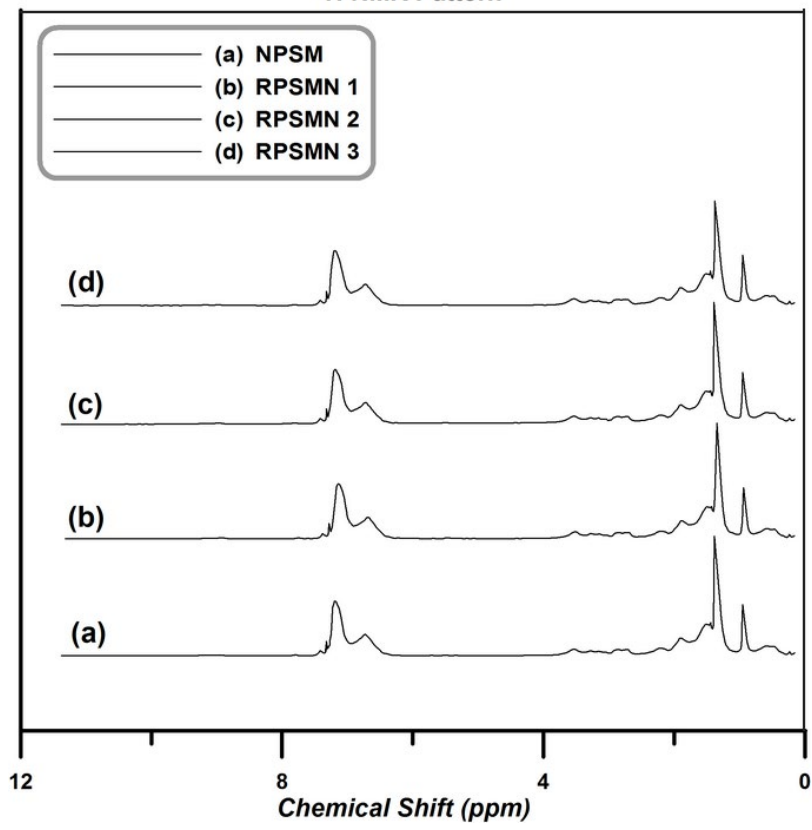

Figure 8: ${ }^{1} \mathrm{H}$ NMR spectra of the neat poly (styrene-co-methyl methacrylate) and its nanocomposites

ing the copolymerization is an evidence of successful SR\&NI ATRP equilibrium establishment.

Evaluation of the structural composition of copolymer chains and determining molar ratio of each monomer in the copolymer chains can be performed by using ${ }^{1} \mathrm{H}$ NMR spectroscopy. ${ }^{1} \mathrm{H}$ NMR spectra of the neat poly (styrene-co-methyl methacrylate) and its different nanocomposites are presented in figure 8.

Molar ratio of each monomer in the copolymer chains can be determined by integrating aromatic peaks area $\left(\mathrm{D}_{\mathrm{Ph}}\right.$, 6.6-7.4 ppm, 5H) which corresponds to the phenyl ring of styrene and methoxy group of methyl methacrylate $\left(D_{M}\right.$, 3.4-3.8 ppm, $3 \mathrm{H}$ ) by using equations (2) and (3):

$$
\begin{aligned}
& \% S t=\frac{\frac{D_{P h}}{5}}{\left(\frac{D_{P h}}{5}+\frac{D_{M}}{3}\right)} \times 100 \\
& \% M M A=\frac{\frac{D_{M}}{3}}{\left(\frac{D_{P h}}{5}+\frac{D_{M}}{3}\right)} \times 100
\end{aligned}
$$

Table 2: Molecular weights and PDI values of the extracted random poly (styrene-co-methyl methacrylate) chains resulted from SEC traces

\begin{tabular}{lcccccc}
\hline Sample & $\begin{array}{c}\text { Reaction } \\
\text { Time (h) }\end{array}$ & $\begin{array}{c}\text { Conversion } \\
(\mathbf{\%})\end{array}$ & Exp. & Theo. & $\boldsymbol{M}_{\boldsymbol{w}}\left(\mathbf{g ~ m o l}^{-\mathbf{1}}\right)$ & PDI \\
& 10 & 76 & 12893 & 11643 & 15214 & 1.18 \\
NPSM & 10 & 80 & 13241 & 12256 & 16948 & 1.28 \\
RPSMN 1 & 10 & 88 & 14182 & 13482 & 19146 & 1.35 \\
RPSMN 2 & 10 & 92 & 14907 & 14094 & 21466 & 1.44 \\
RPSMN 3 & & & & &
\end{tabular}


The extracted data from ${ }^{1} \mathrm{H}$ NMR spectrum of the neat poly (styrene-co-methyl methacrylate) and its nanocomposites is summarized in table 3 . According to the results, molar ratio of each monomer (styrene and methyl methacrylate) in all the samples is approximately similar to the initial selected mole ratio of the monomers (styrene: $\sim 66.6 \%$ and methyl methacrylate: $\sim 33.3 \%$ ).

Table 3: Extracted data from ${ }^{1} \mathrm{H}$ NMR spectroscopy analysis of the pure poly (styrene-co-methyl methacrylate) and its nanocomposites

\begin{tabular}{lcc}
\hline Sample & \multicolumn{2}{c}{ Mole Ratio (\%) } \\
& St & MMA \\
\hline NPSM & 65 & 35 \\
RPSMN 1 & 68 & 32 \\
RPSMN 2 & 64 & 36 \\
RPSMN 3 & 66 & 34 \\
\hline
\end{tabular}

Thermal stability of the neat poly (styrene-co-methyl methacrylate) and its various nanocomposites are studied by using TGA analysis. TGA thermograms of weight loss as a function of temperature in the temperature range of $25-700{ }^{\circ} \mathrm{C}$ in tow different styles are represented in figure 9. Char values of the samples $\left(\right.$ at $700^{\circ} \mathrm{C}$ ) are also provided in this figure. As it is expected, char values increase by increasing diatomite platelets content. In addition, pristine diatomite leaves $92.13 \%$ char after complete degradation at $700{ }^{\circ} \mathrm{C}$.

According to the figure 9, thermal stability of the neat poly (styrene-co-methyl methacrylate) is lower than all of the nanocomposites. In addition, by adding diatomite platelets in the poly (styrene-co-methyl methacrylate) matrix, thermal stability of the neat poly (sty- rene-co-methyl methacrylate) is improved. Moreover, by increasing diatomite platelets content in the nanocomposites samples (RPSMN 1-3), an increase in degradation temperatures was observed. Each TGA thermograms can be divided into three separated degradation steps; $i$ ) the weight loss at the temperature range of $100-150{ }^{\circ} \mathrm{C}$ is attributed to the evaporation of the water molecules. $i$ ) the weight loss at the temperature window around $180-350^{\circ} \mathrm{C}$ is ascribed by degradation of volatile materials (such as residual monomer and low molecular weight oligomers). iii) the final weight loss at the temperatures above $380{ }^{\circ} \mathrm{C}$ is attributed to the degradation of the synthesized poly (styrene-co-methyl methacrylate) chains and nanocomposites. ${ }^{38-40}$ Extracted data from TGA curves are summarized in table 4 .

Table 4: Extracted data from TGA curves for the neat copolymer and its nanocomposites

\begin{tabular}{lccc}
\hline Sample & Char (\%) & The main decomposition step $\left({ }^{\circ} \mathbf{C}\right)$ \\
& at 700 ${ }^{\circ} \mathbf{C}$ & Initial point & Final point \\
\hline NPSM & 3.04 & 331 & 442 \\
RPSMN 1 & 4.54 & 334 & 446 \\
RPSMN 2 & 5.81 & 339 & 452 \\
RPSMN 3 & 6.79 & 345 & 459 \\
Diatomite & 92.13 & - & - \\
\hline
\end{tabular}

Figure 10 graphically illustrates the extracted data from TGA graphs. Degradation temperature of the samples versus amount of degradation is employed to show that addition of diatomite platelets in the poly (styrene-co-methyl methacrylate) matrix, results in an improvement of thermal stabilities of the nanocomposites
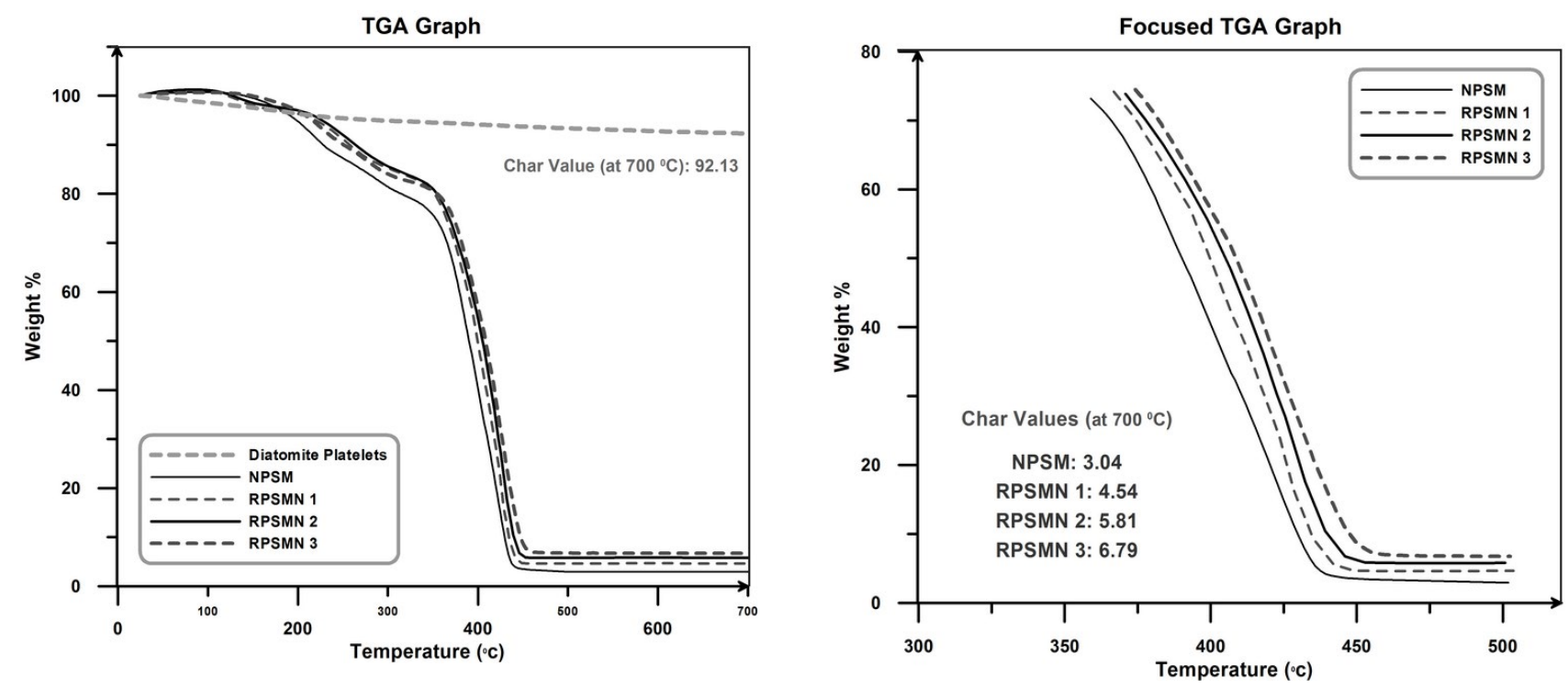

Figure 9: TGA curves of the neat poly (styrene-co-methyl methacrylate) and its nanocomposites in two different styles 


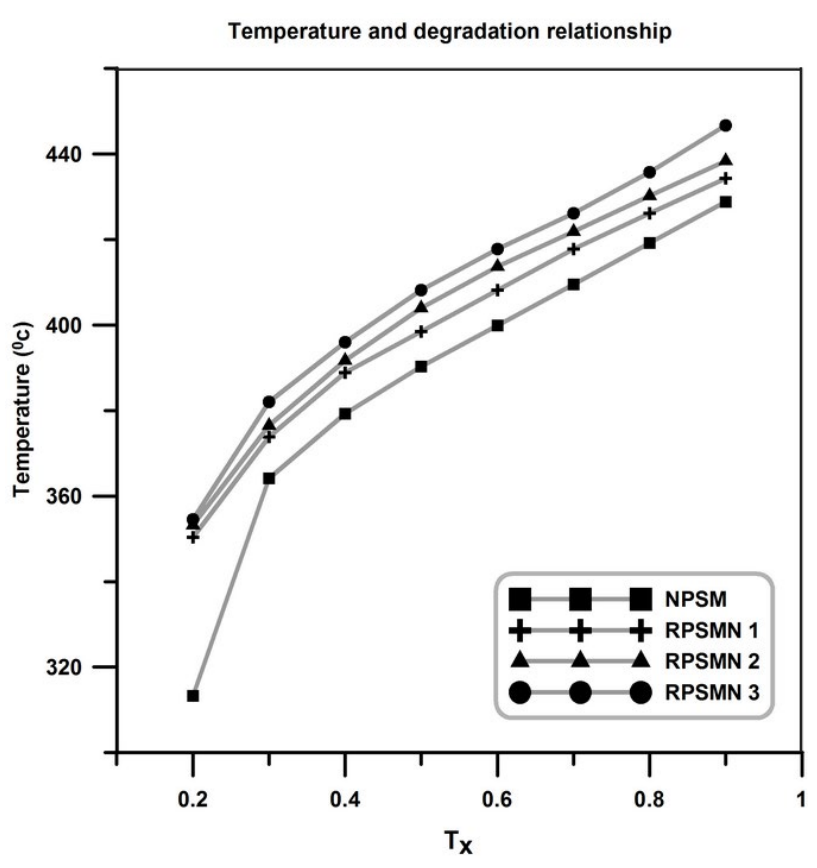

Figure 10: Graphical illustration of temperature and degradation relationship

( $\mathrm{T}_{\mathrm{X}}$ : temperature threshold at which $\mathrm{X} \%$ of poly (styrene-co-methyl methacrylate) and its nanocomposites is degraded).

Improvement in thermal stability of the synthesized sample can be mainly attributed to the high thermal stability of the pristine diatomite platelets and also physical interaction between surface of them and poly (styrene-co-methyl methacrylate) chains. It is clear that by increasing diatomite platelets content, more improvements in thermal stability can be achieved. ${ }^{41-42}$ Moreover, hindrance effect of the diatomite platelets on the copolymer chains movement and restriction of oxygen permeation by these sheets are the other reasons for higher thermal stability of the nanocomposites in comparison with the neat poly (styrene-co-methyl methacrylate). Similar conclusions are also achieved in the case of polymer/clay nanocomposites. ${ }^{43-44}$

DSC analysis is employed to evaluate the effect of diatomite platelets on the chain confinement of the neat poly (styrene-co-methyl methacrylate) and its nanocomposites and also determination of glass transition temperature (Tg) of the prepared samples. DSC curves of the neat poly (styrene-co-methyl methacrylate) and its different nanocomposites are presented in figure 11. Temperature range of $20-200{ }^{\circ} \mathrm{C}$ is used to describe DSC results in the heating path. Diatomite platelets do not bear any transitions in this range of temperature, therefore only thermal transition of random poly (styrene-co-methyl methacrylate) is observed. In these experiments, samples are heated from room temperature to $220^{\circ} \mathrm{C}$ to remove their thermal history. Then, they cooled to room temperature to distinguish

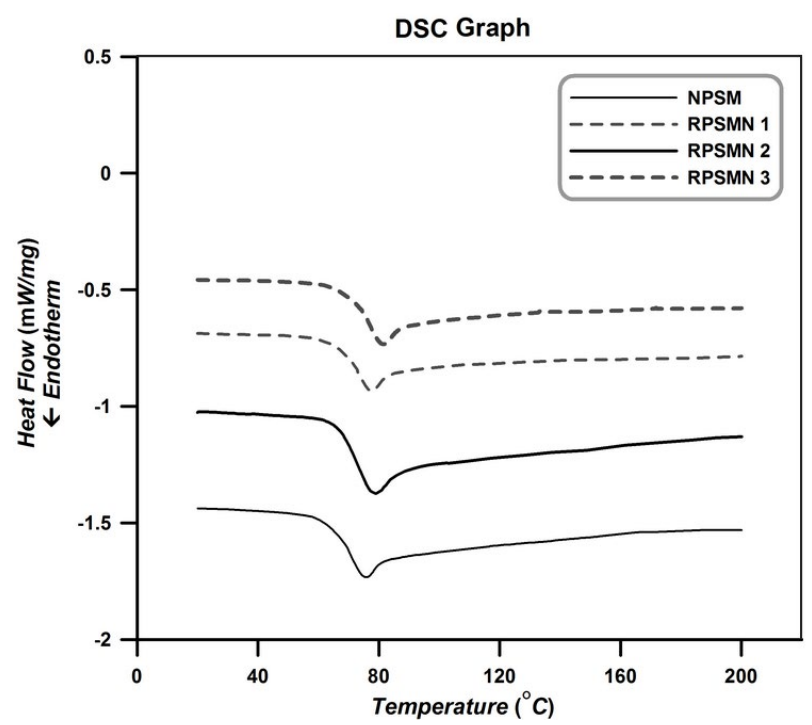

Figure 11: DSC curves of the neat poly (styrene-co-methyl methacrylate) and its nanocomposites

the phase conversion and other irreversible thermal behaviors. Finally, samples are heated from room temperature to $220^{\circ} \mathrm{C}$ to obtain $\mathrm{T}_{\mathrm{g}}$ values.

As it can be seen in figure 11, an obvious inflection in the heating path is occurred in which shows $\mathrm{T}_{\mathrm{g}}$ of the neat random poly (styrene-co-methyl methacrylate) and its various nanocomposites. Corresponding inflection in the cooling path is also appeared. Since there is not another peak in the cooling path, amorphous structure of the synthesized random poly (styrene-co-methyl methacrylate) and its nanocomposites can be concluded. Table 5 summarized the extracted $T_{g}$ values of the samples from DSC curves.

Table 5: Extracted Tg of the neat random poly (styrene-co-methyl methacrylate) and its nanocomposites

\begin{tabular}{lccc}
\hline Sample & $\mathbf{M}_{\mathbf{n}}\left(\mathbf{g ~ m o l}^{-\mathbf{1}}\right)$ & PDI & $\mathbf{T}_{\mathbf{g}}\left({ }^{\circ} \mathbf{C}\right)$ \\
\hline NPSM & 12893 & 1.18 & 67.6 \\
RPSMN 1 & 13241 & 1.28 & 69.5 \\
RPSMN 2 & 14182 & 1.35 & 71.1 \\
RPSMN 3 & 14907 & 1.44 & 73.4 \\
\hline
\end{tabular}

According to the table 5, $\mathrm{T}_{\mathrm{g}}$ value of the nanocomposites (RPSMN 1-3) is higher than neat poly (styrene-co-methyl methacrylate). In addition, an increase in $\mathrm{T}_{\mathrm{g}}$ values is obtained by increasing of diatomite platelets content. Increasing $T_{g}$ values by adding diatomite platelets content in the copolymer matrix can be attributed to the confinement effect of the diatomite platelets. The rigid two-dimensional diatomite platelets can restrict the steric mobility of the random poly (styrene-co-methyl meth- 
acrylate) chains and causes the inflection in the DSC curves starts at higher temperatures. Similar conclusions are also reported in the case of polymer/clay nanocomposites. $^{43-44}$

\section{Conclusions}

In situ SR\&NI ATRP of styrene and methyl methacrylate in the presence of $3 \mathrm{wt} \%$ of mesoporous diatomite platelets leads to increment of conversion and molecular weight from 76 to $92 \%$ and 12893 to $14907 \mathrm{~g} \mathrm{~mol}^{-1}$ respectively. Thus it can be concluded that addition of diatomite platelets results in positive effects on the copolymerization and by addition of diatomite in the copolymerization media, copolymers with higher molecular weight can be achieved. Meanwhile PDI value increases from 1.18 to 1.44. Increment of PDI values indicates that diatomite platelets (such as other nano-fillers) can act as an impurity in the polymerization media. ${ }^{1} \mathrm{H}$ NMR spectroscopy results show that copolymers composition is approximately similar to the initial feed ratio of each monomers. Improvement in thermal stability of the nanocomposites and increasing $\mathrm{T}_{\mathrm{g}}$ values from 67.6 to $73.4^{\circ} \mathrm{C}$ was also observed by incorporation of $3 \mathrm{wt} \%$ of the mesoporous diatomite platelets. Thermal studies can appropriately demonstrate that diatomite behaves similar natural clay platelets and therefore can be considered as a suitable replacement for clay platelets.

\section{References}

1. H. Du, G. Q. Xu, W. S. Chin, Chem. Mater. 2002, 14, 44734479. DOI: $10.1021 / \mathrm{cm} 010622 \mathrm{z}$

2. H. Zou, S. Wu, J. Shen, Chem. Rev. 2008, 108, 3893-3957. DOI:10.1021/cr068035q

3. D. R. Paul, L. M. Robeson, Polymer 2008, 49, 3187-3204. DOI:10.1016/j.polymer.2008.04.017

4. D. W. Schaefer, R. S. Justice, Macromolecules 2007, 40, 85018517. DOI: $10.1021 / \mathrm{ma} 070356 \mathrm{w}$

5. Q. Nguyen, D. Baird, Adv. Polym. Technol. 2006, 25, 270-285. DOI:10.1002/adv.20079

6. S. L. Burkett, N. Ko, N. D. Stern, J. A. Caissie, D. Sengupta, Chem. Mater. 2006, 18, 5137-5143.

DOI:10.1021/cm0614517

7. M. Zanetti, S. Lomakin, G. Camino, Macromol. Mater. Eng. 2000, 279, 1-9.

DOI:10.1002/1439-2054(20000601)279:1<1::AID-MAME1 $>3.0 . \mathrm{CO} ; 2-\mathrm{Q}$

8. S. Varghese, J. Karger-Kocsis, Polymer 2003, 44, 4921-4927. DOI:10.1016/S0032-3861(03)00480-4

9. K. Khezri, V. Haddadi-Asl, H. Roghani-Mamaqani, M. Salami-Kalajahi, J. Appl. Polym. Sci. 2012, 124, 2278-2286. DOI:10.1002/app.35279

10. R. B. Vasani, D. Losic, A. Cavallaro, N. H. Voelcker, J. Mater. Chem. B 2015, 3, 4325-4329. DOI:10.1039/C5TB00648A
11. Z. Jian, P. Qingwei, N. Meihong, S. Haiqiang, L. Na, Appl. Clay Sci. 2013, 83-84, 12-16.

12. P. Yuan, D. Liu, D. Tan, K. Liu, H. Yu, Y. Zhong, A. Yuan, W. $\mathrm{Yu}, \mathrm{H}$. He, Micropor. Mesopor. Mater. 2013, 170, 9-19. DOI:10.1016/j.micromeso.2012.11.030

13. Y. Jia, W. Han, G. Xiong, W. Yang, Sci. Technol. Adv. Mater. 2007, 8, 106-109. DOI:10.1016/j.stam.2006.10.003

14. W. T. Tsai, K. J. Hsien, Y. M. Chang, C. C. Lo, Bioresource Technol. 2005, 96, 657-663.

DOI:10.1016/j.biortech.2004.06.023

15. Y. Wang, J. Cai, Y. Jiang, X. Jiang, D. Zhang, Appl. Microbiol. Biotechnol. 2013, 97, 453-460.

DOI:10.1007/s00253-012-4568-0

16. S. Nenadović, M. Nenadović, R. Kovačević, L. Matović, B. Matović, Z. Jovanović, J. Grbović Novaković, Sci. Sint. 2009, 41, 309-317. DOI:10.2298/SOS0903309N

17. X. Qi, M. Liu, Z. Chen, R. Liang, Polym. Adv. Technol. 2007, 18, 184-193. DOI:10.1002/pat.847

18. Y. S. Al-Degs, M. F. Tutunju, R. A. Shawabkeh, Separ. Sci. Technol. 2000, 35, 2299-2310. DOI:10.1081/SS-100102103

19. C. J. Hawker, A. W. Bosman, E. Harth, Chem. Rev. 2001, 101, 3661-3688. DOI:10.1021/cr990119u

20. G. Moad, Y. K. Chong, A. Postma, E. Rizzardo, S. H. Thang, Polymer 2005, 46, 8458-8468.

DOI:10.1016/j.polymer.2004.12.061

21. K. Matyjaszewski, J. Xia, Chem. Rev. 2001, 101, 2921-2990. DOI:10.1021/cr940534g

22. S. Karaman, A. Karaipekli, A. Sarı, A. Bicer, Solar Energy Mater. Solar Cells 2011, 95, 1647-1653.

DOI:10.1016/j.solmat.2011.01.022

23. X. Li, C. Bian, W. Chen, J. He, Z. Wang, N. Xu, G. Xue, Appl. Surf. Sci. 2003, 207, 378-383.

DOI:10.1016/S0169-4332(03)00010-2

24. X. Li, X. Li, G. Wang, Appl. Surf. Sci. 2005, 249, 266-270. DOI:10.1016/j.apsusc.2004.12.001

25. S. Hu, X. Zhu, W. Hu, L. Yan, C. Cai, Polym. Bull. 2013, 70, 517-533. DOI:10.1007/s00289-012-0849-0

26. J. Z. Liang, Polym. Test. 2008, 27, 936-940. DOI:10.1016/j.polymertesting.2008.08.001

27. G. Sheng, H. Dong, Y. Li, J. Environmental Radioactivity 2012, 113, 108-115. DOI:10.1016/j.jenvrad.2012.05.011

28. Y. Yu, J. Addai-Mensah, D. Losic, Sci. Technol. Adv. Mater. 2012, 13, 015008 (11pp).

29. K. Khezri, Y. Fazli, J. Inorg. Organomet. Polym. 2017, 27, 266274. DOI:10.1007/s10904-016-0469-5

30. N. Garderen, F. J. Clemens, M. Mezzomo, C. P. Bergmann, T. Graule, Appl. Clay Sci. 2011, 52, 115-121.

DOI:10.1016/j.clay.2011.02.008

31. Y. Du, J. Yan, Q. Meng, J. Wang, H. Dai, Mater. Chem. Phys. 2012,133,907-912. DOI:10.1016/j.matchemphys.2012.01.115

32. D. Liu, P. Yuan, D. Tan, H. Liu, T. Wang, M. Fan, J. Zhu, H. He, J. Colloid Interf. Sci. 2012, 388, 176-184.

DOI:10.1016/j.jcis.2012.08.023

33. M. Li, N. M. Jahed, K. Min, K. Matyjaszewski, Macromolecules 2004, 37, 2434-2441. DOI:10.1021/ma035712z

34. H. Roghani-Mamaqani, V. Haddadi-Asl, M. Najafi, M. Sala- 
mi-Kalajahi, Polym. Compos. 2010, 31, 1829-1837.

DOI:10.1002/pc.20975

35. M. Sarsabili, M. Parvini, M. Salami-Kalajahi, A. Asfadeh, Iran. Polym. J. 2013, 22, 155-163.

DOI:10.1007/s13726-012-0114-2

36. Y. Fazli, K. Khezri, Colloid Polym. Sci. 2017, 295, 247-257. DOI:10.1007/s00396-016-3997-1

37. M. Sarsabili, R. Rahmatolahzadeh, S. A. Shobeiri, M. Hamadanian, A. Farazin, K. Khezri, Polym. Adv. Technol. 2018, 29, 424-432. DOI:10.1002/pat.4131

38. K. Khezri, H. Roghani-Mamaqani, Mater. Res. Bull. 2014, 59, 241-248. DOI:10.1016/j.materresbull.2014.07.021

39. K. Khezri, H. Mahdavi, Micropor. Mesopor. Mater. 2016, 228,
132-140. DOI:10.1016/j.micromeso.2016.03.022

40. L. D. Perez, J. F. Lopez, V. H. Orozco, T. Kyu, B. L. Lopez, J. Appl. Polym. Sci. 2009, 111, 2229-2237.

DOI:10.1002/app.29245

41. S. Subramania, S. W. Choia, J. Y. Lee, J. H. Kim, Polymer 2007, 48, 4691-4703. DOI:10.1016/j.polymer.2007.06.023

42. M. A. Ver Meer, B. Narasimhan, B. H. Shanks, S. K. Mallapragada, ACS Appl. Mater. Interf. 2010, 2, 41-47.

43. H. Roghani-Mamaqani, V. Haddadi-Asl, M. Najafi, M. Salami-Kalajahi, J. Appl. Polym. Sci. 2011, 120, 1431-1438.

DOI:10.1002/app.33119

44. H. Roghani-Mamaqani, V. Haddadi-Asl, M. Najafi, M. Salami-Kalajahi, AIChE J. 2011, 57, 1873-1881.

DOI:10.1002/aic.12395

\section{Povzetek}

Mezoporozne diatomitne ploščice smo uporabili za pripravo poli(stiren-co-metil metakrilat) / diatomitnih kompozitov. Za pripravo smo uporabili tehniko polimerizacije s prenosom atoma (Atom transfer radical polymerization ATRP; simultaneous reverse and normal initiation SR\&NI ATRP). Same diatomintne ploščice smo preučili z vrstično elektronsko mikroskopijo (SEM) in presevno elektronsko mikroskopijo, njihovo poroznost pa določili z adsorcijo in desorpcijo dušika. Konverzijo in molekulsko maso smo določili s plinsko kromatografijo (GC) in velikostno izključitveno kromatografijo (SEC). Dodatek 3 ut\% diatomita je vodil v povečanje pretvorbe s $76 \%$ na $92 \%$. Molekulska masa verig poli (stiren-cometil metakrilata) se je povečala od $12893 \mathrm{~g} \mathrm{~mol}^{-1}$ na $14907 \mathrm{~g} \mathrm{~mol}^{-1}$. Indeks polidisperznosti se je povečal z 1,18 na 1,44 . Sestavo kopolimera smo preučili z uporabo NMR spektroskopije. Povečano termično stabilnost nanokompozita smo dokazali s termogravimetrično analizo (TGA). Rezultati diferenčne dinamične kalorimetrije (DSC) kažejo na zvišanje temperature steklastega prehoda $\left(\mathrm{T}_{\mathrm{g}}\right) \mathrm{s} 67,6^{\circ} \mathrm{C}$ na $73,4^{\circ} \mathrm{C} \mathrm{z}$ v primeru dodatka 3 ut $\%$ mezoporoznih diatomitnih ploščic. 